\title{
FILTER PAPER ELECTROPHORESIS OF HUMAN HEMOGLOBIN
}

\author{
By DANIEL L. LARSON ${ }^{1}$ AND HELEN M. RANNEY \\ (From the Department of Medicine, Columbia University College of Physicians and Surgeons, \\ and the Presbyterian Hospital in the City of New York)
}

(Submitted for publication June 4, 1953; accepted June 24, 1953)

Since the observations of Pauling, Itano, Singer, and Wells on the presence of abnormal hemoglobin in the blood of patients with familial anemias, there has been a need for a rapid and simple method for the electrophoretic study of hemoglobin $(1,2)$. Following the earlier work describing techniques of filter paper electrophoresis (3-7), a number of studies have been made on the use of this method for the separation of proteins. Filter paper electrophoresis does not require elaborate equipment and can be adapted for the quantitative estimation of protein patterns yielding information similar to that obtained with free electrophoresis.

Spaet (8) has recently described the identification of abnormal hemoglobins using the Durrum apparatus for paper electrophoresis (7). The present communication will outline the methods used in filter paper electrophoresis of human hemoglobin using the technique described by Kunkel and Tiselius (9). With filter paper electrophoresis it is possible to obtain both qualitative and quantitative data on mixtures of hemoglobins; the presence of an electrophoretically abnormal hemoglobin can be established, its relative concentration determined, and an elution curve may be constructed.

\section{MATERIALS}

Electrical. Power supply unit with a variable voltage over a range of about 600 volts; ammeter with a range of 0 to 25 milliamperes; $8 / 4$ inch carbon electrodes.

Filter paper. Whatman No. 3 MM.

Staining. Stock solution of 1 per cent brom-phenolblue in ethyl alcohol, saturated with mercuric chloride, diluted $1: 50$ for use with 0.5 per cent acetic acid. Rinsing solution of 0.5 per cent acetic acid.

Glassware. One pair 8 by 30 centimeter glass plates for preparative or qualitative work; one pair 20 by 45 centimeter glass plates for quantitative work; one pair 1 liter rectangular battery jars for filter paper bath in preparative work; one pair 4 liter containers with covers for filter paper bath in quantitative work; glass cylinders for staining and rinsing.

1 John and Mary R. Markle Scholar in Medical Science.
Buffer. Veronal buffer $0.025 \mathrm{M}, \mathrm{pH} 8.6$, ionic strength 0.025 . This buffer, made by dissolving 0.69 gram veronal and 4.38 grams of sodium veronal in one liter of distilled water, is used for filter paper baths, dilution of hemoglobin and dialysis of hemoglobin.

Sealing. Silicone stopcock grease for establishing a nonwettable surface on glass plates next to filter paper; Apiezon compound to form airtight seal along exposed edges of glass plates.

Hemoglobin preparation. 0.9 per cent sodium chloride, toluene, carbon monoxide gas.

Quantitative reagents. For tyrosine group determination, 12.5 per cent sodium carbonate, 0.1 per cent copper sulphate, $0.15 \mathrm{~N}$ sodium hydroxide, Folin reagent (10). For dye-elution technique, 0.1 per cent sodium hydroxide. Use of these reagents in association with the electrophoretic analysis of other proteins has been previously described (9).

\section{METHODS}

Hemoglobin for use in these studies was prepared by the method of Drabkin (11), and converted to the more stable carboxyhemoglobin. Some of the specimens were dialyzed before electrophoretic analysis; this was carried out at $4^{\circ} \mathrm{C}$. against $0.025 \mathrm{M}$ veronal buffer at $\mathrm{pH} 8.6$ over a period of two to six days. A final concentration of hemoglobin of approximately 4 grams per cent was used in the runs. Dilutions of hemoglobin were made with the veronal buffer.

The two filter paper baths and the two electrode jars were filled with buffer, and preliminary equilibration of the levels of buffer in the four containers was insured by the use of a siphon which could be clamped off or removed during the run. A sheet of filter paper was cut to fit the width of the glass plates, allowing about 5 to 10 centimeters of overlap at the ends of the plates. The smoother side of the paper was selected as the face or upper side. A baseline was established midway between the two ends of the paper and sites of placement for the hemoglobin were marked along the baseline. Other data such as time of run, voltage, buffer, $\mathrm{pH}$, volume and concentration were written directly on the paper. The marked filter paper was dipped in the buffer solution, then blotted for one or two minutes on a second piece of filter paper. The glass plates were polished on one side with a cloth containing a small amount of silicone stopcock grease to form a non-wettable surface next to the filter paper. The damp-dry, labeled filter paper was then placed on one of the glass plates, centering it carefully so as to give equal overlap of the paper at each end of the plate. 
For the qualitative or preparative runs, 0.005 milliliter samples of a 4 per cent solution of carboxyhemoglobin were placed on a sheet cut to fit the smaller set of glass plates. Five samples could easily be run on a single sheet without crowding. After placing the samples on the paper, the second glass plate was laid directly over the lower plate. Apiezon compound was molded along the exposed edges of the glass plates to reduce evaporation of buffer from the filter paper during the run. The glass plates were placed on the edges of the opposing sides of the filter paper baths allowing the filter paper to extend closely down the inner side of the containers and into the buffer solution. Additional pressure on the plates may be obtained by adding 1 or 2 pounds of weight to the top of the plates after they are in place thus insuring a straight path of migration of the hemoglobin. The horizontal position of the glass plates was established with a spirit level and after a period of five minutes for equilibration, the siphon was removed or clamped off, and the current was applied. The preparative runs were made at 600 volts over a period of four to five hours. The paper was then removed from the plates and allowed to dry. Drying the paper before staining prevented the appearance of central pallor in a spot of high protein concentration. The dried paper was dropped into a cylinder of dye for 10 minutes, and then rinsed for several minutes in each of three successive acetic acid baths. After drying, the stained paper was passed through ammonia vapor to develop the blue color.

For a quantitative estimation of the protein pattern produced, the larger set of plates was used; this permitted use of larger volumes of hemoglobin solution in each spot and a longer run. The plates and paper were prepared as in the qualitative run, and 0.02 milliliter samples of a 4 per cent solution of carboxyhemoglobin were plated on the paper. The run was carried out at 600 volts over a period of 15 hours. Under these conditions, the migration of the spots from the baseline at the end of 15 hours varied from about 15 centimeters to 25 centimeters, depending upon the type of hemoglobin under examination. After removal of the paper from the plates and drying, samples to be analyzed with the dye-elution technique were stained as in the preparative runs, while samples to be analyzed with the Folin method were not stained. In either case, the papers were then placed on a medium sized paper cutter, and $1 / 4$-inch strips were cut from the paper parallel to the baseline, beginning at the point of maximum migration of hemoglobin and working back toward the baseline. These strips were numbered, and each in turn was cut perpendicular to the baseline, between the paths of migration of the hemoglobin samples. This provided a number of small pieces of filter paper, each representing a sample of known position from one of the carboxyhemoglobin specimens included in the run. With the dye-elution technique the pieces of paper were placed in separate tubes and the dye was eluted with 6 milliliter portions of 0.1 per cent sodium hydroxide and allowed to stand for one hour at room temperature. The optical density of the blue color was then read against a filter paper blank in a Coleman Universal spectrophotometer at $\mathbf{5 7 5}$ millimicrons. With the Folin method the protein was eluted from each piece of paper by allowing it to stand overnight in $2 \mathrm{ml}$. of 0.15 $\mathrm{N}$ sodium hydroxide. After elution, $1 \mathrm{ml}$. of 0.1 per cent copper sulfate and $6.0 \mathrm{ml}$. of 12.5 per cent sodium carbonate were added to the tubes. After one hour at room temperature, $1.0 \mathrm{ml}$. of Folin reagent, freshly diluted with twice its volume of distilled water, was added dropwise with shaking. After 15 minutes, the optical density of the blue color developed was read against a filter paper blank in a Coleman Universal spectrophotometer at 650 millimicrons.

The values obtained for the optical density using either the dye-elution technique or the Folin method may be plotted against the distance from the baseline and a curve obtained which resembles the configuration seen in moving boundary electrophoresis.

For many clinical purposes, a semi-quantitative method was adequate. This method was designed to provide information on the relative amounts of each component in a mixture of hemoglobins, expressed as a percentage of the total hemoglobin present. This information was obtained by using a 4 per cent solution of carboxyhemoglobin and employing the same technique used in the preparative run. The paper was stained and dried in the usual manner, and the separate components in the mixture were cut out, placed in individual tubes and the dye eluted with 6 milliliters of 0.1 per cent sodium hydroxide. The optical density of the solution is read at $\mathbf{5 7 5}$ millimicrons against a filter paper blank and the relative concentrations of the components established. Suitable known control samples of hemoglobin run with the unknown samples aid in accuracy of cutting out the spots.

\section{RESULTS}

Time of run. For preparative and semi-quantitative work, with the smaller plates, four or five hours were usually sufficient to establish the presence or absence of abnormal hemoglobin. The information so obtained was adequate for many clinical situations. For quantitative analyses, the greater migration of a 15-hour run permitted adequate sampling for the construction of an accurate elution curve. In certain instances, better separation of two hemoglobins was obtained with the lunger than with the shorter run.

Voltage. Voltages up to 2,000 were used in various experiments. No significant advantage was noted using voltages in excess of 600 , and 300 volts or less may be satisfactory for most purposes. The amperage at 600 volts was 2 to 4 milliamperes using the small plates and 7 to 9 milliamperes using the large plates. Veronal buffer of relatively low ionic strength, i.e., 0.05, permitted operation at higher voltages without introducing a heating effect associated with increased amperage. 
Buffer $p H$. Using relatively large volumes of buffer in the filter paper baths and placing the electrodes in separate containers tended to reduce $\mathrm{pH}$ changes during operation. The buffer was usually changed after three or four runs. Runs were made in cacodylate, phosphate and veronal buffers at $\mathrm{pH}$ values over a range of 6.5 to 9.2. It was possible to adjust the $\mathrm{pH}$ so that normal hemoglobin moved toward the positive pole and abnormal hemoglobin moved toward the negative pole, but no particular advantage was noted with this technique. Normal carboxyhemoglobin remained at the baseline at a pH of about 7.5. Runs made at a $\mathrm{pH}$ below 7.6 were less satisfactory due to increased trailing and smudging which produced less distinct spots. The most satisfactory buffer for both qualitative and quantitative analyses was veronal at $\mathrm{pH}$ 8.6.

Effect of volume and concentration of hemoglobin. Minor inaccuracies in pipetting or in concentration did not appear to affect the mobility. Volumes of hemoglobin solution greater than 0.02 and 0.03 milliliter caused considerable lateral spreading of the samples during the run. No attempt was made to use several layers of filter paper to increase the capacity of the system. In qualitative and semi-quantitative work, 0.005 milliliter samples were quite suitable, and for construction of an elution curve, 0.02 milliliter samples were used. Carboxyhemoglobin concentrations of 4 per cent gave neat appearing papers with well-defined pro- tein spots, easily recognized before, as well as after, staining.

Effect of dialysis. Dialysis of the carboxyhemoglobin solutions at $4^{\circ} \mathrm{C}$. against several changes of veronal buffer was carried out on a number of specimens. The most notable effect of prolonged dialysis was the elimination of a small amount of "head-trailing" present in some samples of undialyzed carboxyhemoglobin. Therefore, dialysis was considered to be unnecessary for most purposes. The final dilution of carboxyhemoglobin to the 4 per cent concentration used in the runs was carried out with veronal buffer of $\mathrm{pH}$ 8.6.

Effect of conversion of hemoglobin to carboxyhemoglobin. All hemoglobin samples were converted to the more stable carboxyhemoglobin before storage. This conversion did not appear to affect the mobility of the samples.

Effect of size of paper and plates. Using 0.005 milliliter samples, five separate hemoglobin preparations could be run simultaneously with the 8 by 30 centimeter glass plates. The larger plates are preferable for quantitative work because of a greater migration, larger volumes, increased sampling, and greater accuracy of elution curves. In addition, as many as eight or ten samples may be run simultaneously with the larger plates, and compared quantitatively after treatment under identical conditions.

Calibration curves. With the Folin method, increasing volumes of hemoglobin were added di-

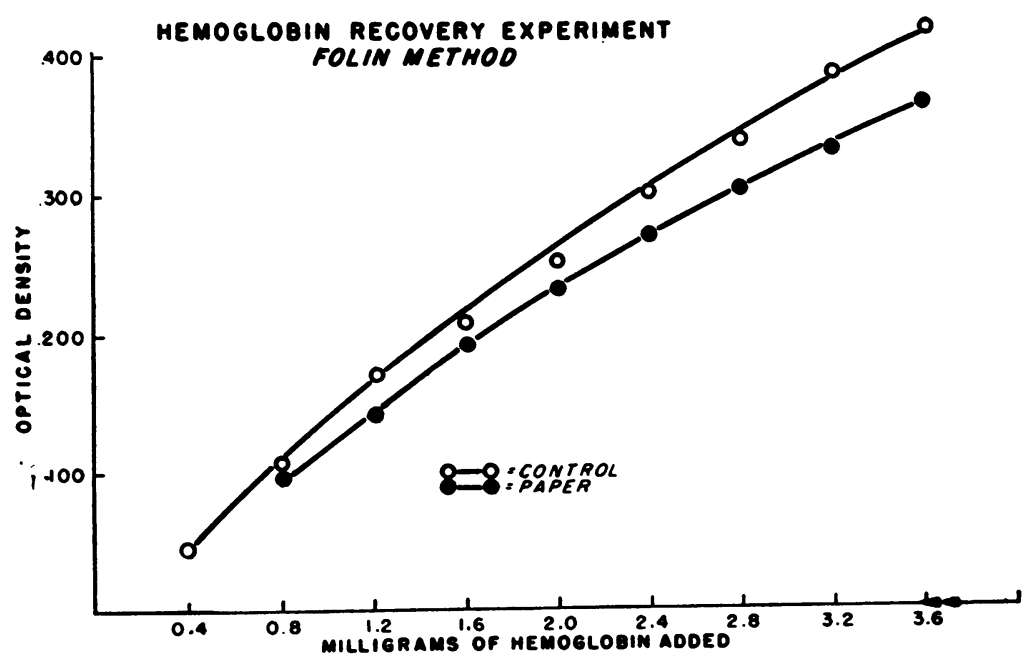

Fig. 1. Calibration Curve for the Measurement of Hemoglobin Using the Method of Folin and Ciocalteu 
TABLE I

Recovery experiments with artificial mixtures of normal and sickle hemoglobin-semi-quantitative technique, dye-elution method

\begin{tabular}{|c|c|c|c|c|c|}
\hline \multicolumn{2}{|c|}{$\begin{array}{l}\text { Mixture of } 90 \% \\
\text { normal and } \\
10 \% \text { sickle } \\
\text { hemoglobin }\end{array}$} & \multicolumn{2}{|c|}{$\begin{array}{l}\text { Minture of } 75 \% \\
\text { normal and } \\
25 \% \text { sickle } \\
\text { hemoglobin }\end{array}$} & \multicolumn{2}{|c|}{$\begin{array}{l}\text { Mixture of } 50 \% \\
\text { normal and } \\
50 \% \text { sickle } \\
\text { hemoglobin }\end{array}$} \\
\hline Normal & Sickle & Normal & Sickle & Normal & Sickle \\
\hline \multicolumn{6}{|c|}{ Per cent of each hemoglobin reconered } \\
\hline $\begin{array}{l}86 \\
85 \\
82 \\
84 \\
88 \\
90 \\
90 \\
90 \\
89 \\
87 \\
89\end{array}$ & $\begin{array}{l}14 \\
15 \\
18 \\
16 \\
12 \\
10 \\
10 \\
10 \\
11 \\
13 \\
11\end{array}$ & $\begin{array}{l}75 \\
68 \\
73 \\
71 \\
72 \\
76 \\
70 \\
66 \\
70 \\
67 \\
73 \\
70 \\
67\end{array}$ & $\begin{array}{l}25 \\
32 \\
27 \\
29 \\
28 \\
24 \\
30 \\
34 \\
30 \\
33 \\
27 \\
30 \\
33\end{array}$ & $\begin{array}{l}52 \\
46 \\
46 \\
49 \\
50 \\
49 \\
48 \\
52 \\
53 \\
48 \\
50\end{array}$ & $\begin{array}{l}\mathbf{4 8} \\
\mathbf{5 4} \\
\mathbf{5 4} \\
\mathbf{5 1} \\
\mathbf{5 0} \\
\mathbf{5 1} \\
\mathbf{5 2} \\
\mathbf{4 8} \\
\mathbf{4 7} \\
\mathbf{5 2} \\
\mathbf{5 0}\end{array}$ \\
\hline
\end{tabular}

rectly to the tubes and these values plotted against the optical density. An essentially linear relation was obtained over the range of 0.100 to 0.500 . Optimal amounts of hemoglobin for measurement with the dye-elution technique are of the order of 20 to 100 micrograms, and with the Folin method of the order of 0.3 to 1.5 milligrams. See Figure 1 . For the dye-elution technique, increasing amounts of a hemoglobin solution were added to paper, and these values were plotted against the optical density of the eluted dye. An essentially straight line relation was obtained in the region of greatest sensitivity of the spectrophotometer at an optical density of 0.100 to 0.500 .

Recovery experiments. With the dye-elution technique, known artificial mixtures of normal and sickle hemoglobin were run as in the semi-quantitative method and the relative concentrations determined. The data recorded in Table I indicate a recovery satisfactory for most clinical purposes. With the Folin method, values were compared for hemoglobin samples placed directly in the tubes with identical amounts placed on paper and then eluted with alkali. The lower curve in Figure 1 indicates approximately a 90 per cent recovery.

In Table II, figures obtained with the semiquantitative technique are presented on the analysis of hemoglobin specimens from patients with sickle cell trait and sickle cell anemia. Among the patients with sickle cell trait, the values for sickle hemoglobin ranged from about 35 per cent to about 50 per cent. Among the patients with sickle cell anemia, the values for sickle cell hemoglobin were usually near 100 per cent, although one was as low as 72 per cent. It should be pointed out, however, that the mobility of fetal hemoglobin is intermediate between normal and sickle hemoglobin, and when fetal hemoglobin is mixed with either normal or sickle hemoglobin the fetal component cannot be readily distinguished by filter paper electrophoresis. For this reason, some of the values reported as sickle cell hemoglobin in patients with sickle cell anemia may be falsely high, due to admixture with unrecognized fetal hemoglobin.

Application of the quantitative technique. Elution curves were constructed for hemoglobins obtained from patients with a variety of anemias. In each case, the hemoglobin was run on the same piece of paper with a normal control. Hemoglobin obtained from patients with iron deficiency anemia, pernicious anemia, pernicious anemia with a 10 per cent reticulocyte response following the administration of Vitamin $B_{12}$, and congenital and acquired hemolytic anemia, all had elution curves identical with those of the normal control.

In Figures 2 and 3, elution curves are shown for five different hemoglobin patterns; all were obtained from a single sheet of paper in a single run. Patterns included are (1) normal, (2) sickle cell trait, (3) sickle cell anemia, (4) hemoglobin C

TABLE II

Semi-quantitative analysis of hemoglobins from patients with sickle cell anemia and with sickle cell traitdye-elution technique*

\begin{tabular}{|c|c|c|c|c|c|}
\hline \multicolumn{3}{|c|}{ Sickle cell trait } & \multicolumn{3}{|c|}{ Sickle cell anemia } \\
\hline Patient & $\begin{array}{c}\text { Normal } \\
\text { hgb. } \\
\%\end{array}$ & $\begin{array}{c}\text { Sickle } \\
\text { hgb. } \\
\%\end{array}$ & Patient & $\begin{array}{c}\text { Normal } \\
\text { hgb. } \\
\%\end{array}$ & $\begin{array}{c}\text { Sickle } \\
\text { hgb. } \\
\%\end{array}$ \\
\hline $\begin{array}{r}196 \\
51 \\
56 \\
60 \\
109 \\
112 \\
127 \\
148 \\
149\end{array}$ & $\begin{array}{l}63 \\
60 \\
46 \\
65 \\
52 \\
58 \\
52 \\
55 \\
57\end{array}$ & $\begin{array}{l}37 \\
40 \\
54 \\
35 \\
48 \\
42 \\
48 \\
45 \\
43\end{array}$ & $\begin{array}{r}52 \\
53 \\
57 \\
58 \\
61 \\
101 \\
131 \\
145 \\
150 \\
152 \\
153 \\
176\end{array}$ & $\begin{array}{r}0 \\
5 \\
13 \\
7 \\
28 \\
0 \\
0 \\
19 \\
10 \\
0 \\
0 \\
0\end{array}$ & $\begin{array}{r}100 \\
95 \\
87 \\
93 \\
72 \\
100 \\
100 \\
81 \\
90 \\
100 \\
100 \\
100\end{array}$ \\
\hline
\end{tabular}

*The values reported for "normal" hemoglobin may include some fetal hemoglobin. See text. 
trait, ${ }^{2}$ and (5) the naturally occurring mixture of hemoglobin $\mathrm{C}$ and sickle hemoglobin.

Application of the preparative and semi-quantitative methods. Filter paper electrophoresis of hemoglobin has been carried out on a number of patients with anemias of uncertain etiology, and in certain cases it has proved an extremely useful diagnostic aid. The presence of hemoglobin C, a new abnormal hemoglobin first described by Itano, and Neel (12) and by Kaplan, Zuelzer, and Neel (13), was readily demonstrated by filter paper electrophoresis. This hemoglobin (which was earlier called hemoglobin III or hemoglobin C) was detected in association with normal and with sickle hemoglobin, and in one case hemoglobin $\mathrm{C}$ was the only type of hemoglobin present. The clinical manifestations which are associated with the presence of the gene for hemoglobin $\mathrm{C}$ in the

2 The nomenclature used for the varieties of human hemoglobin is that recommended by the Hematology Study Section of the Division of Research Grants of the National Institutes of Health. Blood, 1953, 8, 386. homozygous state and in the heterozygous states will be reported in a separate communication (14).

In addition to its usefulness in the detection of other abnormal hemoglobins, filter paper electrophoresis has been a valuable aid in distinguishing sickle cell trait from sickle cell anemia. While the clinical distinction between sickle cell trait and sickle cell anemia is usually readily made, occasionally patients with sickle cell anemia have their initial symptoms in adult life, or have symptoms of the homozygous sickling state without marked anemia. Other patients are seen who, although their erythrocytes are known to sickle, have other disease processes present which might account for the anemia observed. Although the velocity and morphologic characteristics of the sickling process frequently aid in distinguishing sickle cell trait from sickle cell anemia, it is sometimes difficult to make the distinction on the basis of the sickle cell preparation alone. The degree of reticulocytosis is often of value in distinguishing sickle cell trait from sickle cell anemia; however, patients with

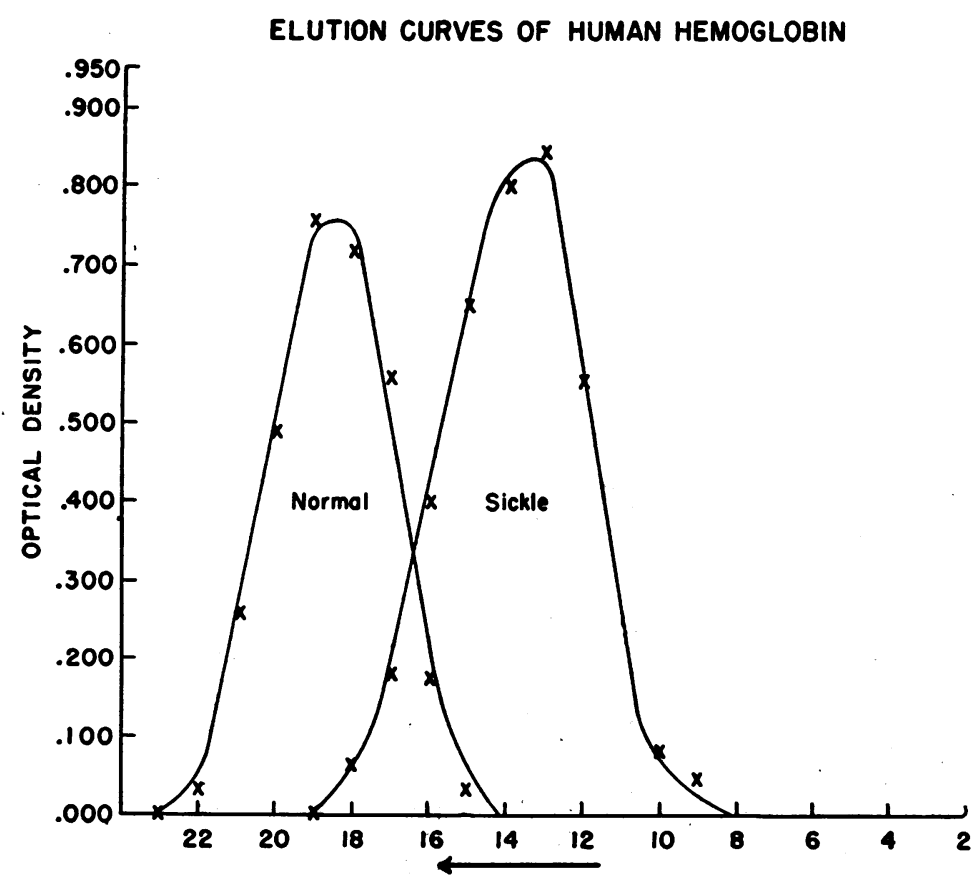

Fig. 2. Dye-Elution Technigue

Abscissa indicates centimeters of movement of the specimens of hemoglobin away from the baseline in the direction of right to left. The elution curves in Figures 2 and 3 were constructed from data obtained running the five species of hemoglobin simultaneousiy on a single sheet of paper. The separation of the curves into two figures is done only for clarity. 


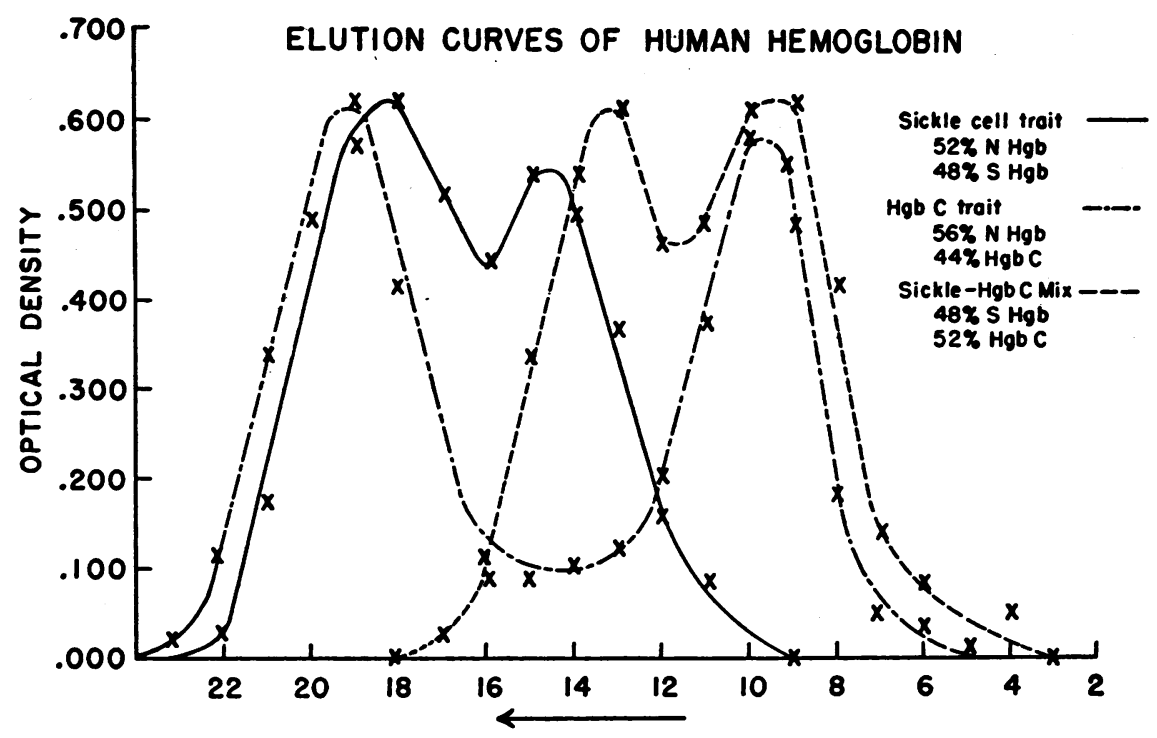

See footnote to Figure 2.

Fig. 3. Dye-Elution Techirigue

sickle cell trait with recent blood loss may have an elevated reticulocyte count and, on the other hand, the reticulocyte count may be normal in certain patients whose hemoglobin is almost entirely of the sickle variety. It should be noted that the very rare double abnormal heterozygote for sickle hemoglobin and hemoglobin $\mathrm{D}(15)$ cannot be distinguished by electrophoresis, since all of the hemoglobin of such an individual would possess the mobility of sickle cell hemoglobin.

While filter paper electrophoresis is a rapid and simple method for the detection of normal adult hemoglobin, sickle hemoglobin and hemoglobin $\mathrm{C}$, it is not satisfactory for the separation of fetal hemoglobin and sickle hemoglobin cannot be differentiated from hemoglobin $D$ by this method. Therefore, filter paper electrophoresis should be combined with resistance to alkali denaturation $(16,17)$ for the estimation of fetal hemoglobin, and the solubility studies (15) for the determination of hemoglobin D.

\section{SUM MARY}

Methods are presented for the qualitative, semiquantitative and quantitative analysis of human hemoglobin using filter paper electrophoresis. The effects of time of run, voltage, buffer $\mathrm{pH}$, volume, concentration, dialysis, conversion to carboxyhemoglobin, size of paper and glass plates are discussed. Data on calibration curves and recovery experiments using the semi-quantitative and quantitative techniques are presented.

\section{REFERENCES}

1. Pauling, L., Itano, H. A., Singer, S. J., and Wells, I. C., Sickle cell anemia, a molecular disease. Science, 1949, 110, 543.

2. Itano, H. A., Human hemoglobin. Science, 1953, 117, 89.

3. Wieland, T., and Fischer, E., Uber elektrophorese auf filtrierpapier. Trennung von Aminosäuren und ihren Kupferkomplexen. Naturwissenschaften, 1948, 35, 29.

4. Turba, F., and Enenkel, H. J., Elektrophorese von proteinen in Filtrierpapier. Naturwissenschaften, 1950, 37, 93.

5. Cremer, H. D., and Tiselius, A., Elektrophorese von Eiweiss in Filtrierpapier. Biochem. Ztschr., 1950, 320, 273.

6. Grassman, W., and Hannig, K., Ein einfaches Verfahren zur kontinuierlichen Trennung von Stoffgemischen auf Filterpapier durch Elektrophorese. Naturwissenschaften, 1950, 37, 397.

7. Durrum, E. L., A microelectrophoretic and microionophoretic technique. J. Am. Chem. Soc., 1950, 72, 2943.

8. Spaet, T. H., Identification of abnormal hemoglobins by means of paper. electrophoresis. J. Lab. \& Clin. Med., 1953, 41, 161.

9. Kunkel, H. G., and Tiselius, A., Electrophoresis of proteins on filter paper. J. Gen. Physiol., 1951, 35, 89.

10. Folin, O., and Ciocalteu, V., On tyrosine and tryptophane determinations in proteins. J. Biol. Chem., 1927, 73, 627. 
11. Drabkin, D. L., Spectrophotometric studies. XIV. The crystallographic and optical properties of the hemoglobin of man in comparison with those of other species. J. Biol. Chem., 1946, 164, 703.

12. Itano, H. A., and Neel, J. V., A new inherited abnormality of human hemoglobin. Proc. Nat. Acad. Sc., 1950, 36, 613.

13. Kaplan, E., Zuelzer, W. W., and Neel, J. V., A new inherited abnormality of hemoglobin and its interaction with sickle cell hemoglobin. Blood, 1951, 6, 1240.

14. Ranney, H. M., and Larson, D. L., In preparation.
15. Itano, H. A., A third abnormal hemoglobin associated with hereditary hemolytic anemia. Proc. Nat. Acad. Sc., 1951, 37, 775.

16. Ponder, E., and Levine, P., Fetal and adult hemoglobins in the blood of infants affected with hemolytic disease of the newborn. Blood, 1949, 4, 1264.

17. Singer, K., Chernoff, A. I., and Singer, L., Studies on abnormal hemoglobins. I. Their demonstration in sickle cell anemia and other hematologic disorders by means of alkali denaturation. Blood, 1951, 6, 413. 